Katarzyna Bagan-Kurluta

Uniwersytet w Biatymstoku

Bartłomiej Oszkinis

Uniwersytet w Biatymstoku

\title{
KOREKCYJNA FUNKCJA SŁUSZNOŚCI W PRAWIE RODZINNYM - KILKA REFLEKSJI NA MARGINESIE WYROKU M.R \& ANOR -V- AN TARD CHLARAITHEOIR \& ORS
}

Dnia 5 marca 2013 r. do irlandzkiego High Court wpłynęła sprawa M.R \& Anor -v- An tArd Chlaraitheoir \& Ors ${ }^{1}$ o ustalenie, komu przysługuje status rodziców bliźniąt (zwłaszcza matki) i w konsekwencji, na kim spoczywają prawa i obowiązki w zakresie realizacji funkcji rodzicielskiej. Rozstrzygnięcia tej kwestii domagało się w imieniu swoim i bliźniąt małżeństwo OR i CR. Jak wynika ze stanu faktycznego, kobieta (CR) nie była w stanie urodzić dziecka w normalny sposób, więc po uzgodnieniu dalszego postępowania ze swoją siostrą (L), dostarczyła własne komórki jajowe, które zostały zapłodnione w warunkach in vitro nasieniem jej męża (OR), a zygoty wyprodukowane w wyniku tego zapłodnienia zostały wszczepione wspomnianej siostrze. Efektem donoszonej ciąży było urodzenie przez L bliźniąt (MR i DR). Jeszcze przed ich przyjściem na świat uzgodniono, że będą one wychowywane jako dzieci CR i OR - co miało zresztą później miejsce. W rzeczywistości bowiem OR był tzw. genetycznym ojcem dzieci, CR - ich tzw. genetyczną matką, natomiast jej siostra - tzw. matką gestacyjną, czyli kobietą, która je urodziła. Między tymi trzema osobami nie doszło do sporu dotyczącego statusu ich i ich dzieci, jednakże para CR i OR chciała, oprócz faktycznego sprawowania funkcji rodziców, uchodzić za rodziców swoich dzieci genetycznych również w świetle prawa. Trudność ich sytuacji związana była z faktem, że irlandzkie prawo traktuje jak matkę kobietę, która urodziła dziecko. W związku z tym, po urodzeniu się bliźniaków siostra CR (matka gestacyjna) i OR (genetyczny ojciec dzieci) udali się do urzędu stanu cywilnego $^{2}$ i zostali zarejestrowani jako ich rodzice. Jednakże już po tej rejestracji

[2013]IEHC 91.

Registrar's office. 
wysłali do centralnego urzędu odpowiedzialnego za rejestrację danych dotyczących stanu cywilnego ${ }^{3}$ list z dołączonymi do niego wynikami testów DNA z żądaniem korekty błędu, możliwą na podstawie art. 63 Civil Registration Act z 2004 r. Żądanie to zostało odrzucone.

Omówienie postępowania przed High Court, warto poprzedzić kilkoma uwagami na temat specyfiki prawa irlandzkiego. Otóż wywodzi się ono z angielskiej tradycji common law i cały czas się w nią wpisuje. ${ }^{4}$ Stąd też z powodzeniem można do niego odnieść uwagi dotyczące tak źródeł prawa angielskiego, jak i roli orzeczeń precedensowych. Co do pierwszej kwestii, w hierarchii źródeł prawa przyjęto supremację prawa UE i Europejskiej Konwencji Praw Człowieka i Podstawowych Wolności z 1950 r. Zaraz po nich następują: Konstytucja, common law (określić je można mianem ogólnych zasad prawa), statuty (ustawy), precedensy i praktyka. ${ }^{5} \mathrm{~W}$ kontekście katalogu i pierwszeństwa stosowania źródeł prawa to właśnie prawo stanowione jest obecnie najważniejszym źródłem prawa. Jego ranga wynika z faktu, że zdominowało ono wszystkie inne jego źródła, co zresztą wcale nie znaczy, że każdy aspekt życia ludzkiego jest przedmiotem regulacji ustawowej. ${ }^{6}$ Natomiast prawotwórcza funkcja sędziów i sama możliwość tworzenia przez nich prawa wywodzona jest z ich niezawisłości. ${ }^{7}$ Jednakże ich działania mogą być sprowadzone do spełniania roli interpretatorów istniejących już reguł, a nie ich kreatorów, ${ }^{8}$ ewentualnie osób odpowiedzialnych za wypełnianie luk w prawie stanowionym. Kwestia prawotwórczej roli sędziów w systemie common law pozostaje kontrowersyjna od wieków, wciąż aktualne jest pytanie, czy sędziowie powinni wkraczać w sferę zarezerwowaną dla parlamentu, szczególnie gdy sprawa wymaga podjęcia natychmiastowej decyzji, ${ }^{9}$ ewentualnie gdy parlament nie zdecydował się na przyjęcie jakiejś regulacji lub gdy dotyczyć by ona miała problemu społecznego będącego przedmiotem poważnej społecznej dysputy. ${ }^{10}$ Rezerwacja sfery legislacyjnej dla parlamentu i wyznaczenie roli sądom w sposób oczywisty wynika z konstytucji, która, ma pierwszeństwo stosowa-

Superintendent Registrar z siedzibą w Dublinie.

The Courts Service Ireland, http://www.courts.ie/Courts.ie/Library3.nsf/pagecurrent/8B9125171CFBA78080256DE5004011F8?opendocument\&l=en (8.07.2014).

J. Bell, (w:) A. Burrows (red.), English Private Law, Oxford University Press, Oxford 2007, s. 4. Por. K. Bagan-Kurluta, Sprawy rodzinne w polsko-brytyjskim obrocie prawnym, Białystok 2012, s. 19.

C. Elliot, F. Quinn, English Legal System, Harlow 2008, s. 7.

Przykładowo w Wielkiej Brytanii od Act of Settlement z $1700 \mathrm{r}$.

Teoria W. Blackstona: declaratory theory of law.

Por. C. Elliot, F. Quinn, English..., op. cit., s. 22-27 oraz orzecznictwo: C (A Minor) v DPP (1995), Kleinwort Benson Ltd v Lincoln City Coucil (1998), DPP v Jones (1999), McLoughlin v O’Brian (1982), Fitzpatrick v Sterling Housing Association Ltd (2000), President of India v La Pintada Compania Navigacion SA (1984).

C (A Minor) v DPP (1995). 
nia przed innymi źródłami prawa ${ }^{11}$ - także przed common law. ${ }^{12} \mathrm{Na}$ podstawie art. 15 Konstytucji Irlandii uchwalonej przez Naród dnia 1 lipca 1937 r., ${ }^{13}$ jedyną i wyłączną władzę stanowienia ustaw państwa powierzono dwuizbowemu parlamentowi narodowemu ${ }^{14}$ - Oireachtas. Żadna inna władza prawodawcza nie jest uprawniona do stanowienia ustaw w państwie. Natomiast sędziowie sprawują wymiar sprawiedliwości, będąc przy tym niezawiśli w pełnieniu swoich funkcji sędziowskich, ale podlegając tak Konstytucji, jak i ustawom (art. 34.1 i 35.2). Dwuinstancyjny system sądowy umożliwia wyłonienie sądów wyższych instancji, których orzeczenia mogą mieć charakter precedensowy. Takim sądem jest High Court, który rozstrzygał w sprawie M.R \& Arnor -v- An tArd Chlaraitheoir \& Ors. Jest on związany orzeczeniami precedensowymi Supreme Court, natomiast z wyjątkami sytuacji, gdy zasiada jako Divisional Court (a więc zamiast w jednoosobowym gronie - w składzie dwóch lub większej liczby sędziów) - nie jest związany swoimi wcześniejszymi orzeczeniami. Natomiast jego orzeczenia wiążą sądy niższe w hierarchii: Circuit i District Court. ${ }^{15}$ Orzeczenia sądów wyższych instancji mogą mieć charakter precedensowy, a więc wiążący - mogą jednak nie wiązać na przyszłość, ewentualnie być tylko wzorem dla przyjęcia jakiegoś wiążącego rozwiązania jako tzw. persuasive precedents. W myśl zasady stare decisis - let the decision stand, ${ }^{16}$ wiążą te orzeczenia, które: 1) dotyczą zagadnienia prawnego: zawierają stwierdzenie co do prawa (statement of law), a więc uzasadnienie sposobu rozumowania sędziego w odniesieniu do zastosowania prawa ${ }^{17}$ i 2) zawierają ratio decidendi, rozumiane jako prawne umotywowanie decyzji (czyli jakakolwiek reguła prawna wyraźnie lub dająca się w sposób dorozumiany zidentyfikować jako przyjęta przez sędziego za konieczny krok w podjęciu przez niego decyzji - biorąc pod uwagę tok rozumowania sędziego lub niezbędną część jego wskazówek dla przysięgłych). ${ }^{18}$ Ponadto precedens powinien być zgodny $\mathrm{z}$ konstytucją. Stąd też każdy precedens, tak jak akt prawa stanowionego, sprzeczny z regulacją konstytucyjną nie będzie miał mocy wiążącej - jako nieważny nie wywrze skutków prawnych. ${ }^{19} \mathrm{Z}$ drugiej jednak strony, gdy sędzia orzeka na podstawie przepisu statutu, który może być potraktowany dwojako - jako zgodny oraz nie-

11 Z pominięciem aktów prawnych UE.

12 https://e-justice.europa.eu/content_member_state_law-6-ie-pl.do?member=1 (8.07.2014).

13 http://libr.sejm.gov.pl/tek01/txt/konst/irlandia2011.html (8.07.2014).

14 Ale: Oireachtas tworzy Prezydent oraz dwie Izby, a mianowicie: Izba Reprezentantów nosząca nazwę Dáil Éireann i Senat noszący nazwę Seanad Éireann (art. 15.1.2).

Por. Kearns v Manresa Estates Ltd. (High Court, 25 July 1975, unreported), Irish Trust Bank Ltd. v Central Bank of Ireland [1976-7] ILRM 50, McDonnell v Byrne Engineers (High Court, unreported, July 1978), a także informacje zawarte na stronie Associati on of Chartered Certified Accountants, http://www.accaglobal.com/content/dam/ acca/global/pdf/f4irl_2009_jun_a.pdf (8.07.2014).

16 C. Elliott, F. Quinn, English..., op. cit., s. 9-10; M. Koszowski, Anglosaska doktryna precedensu. Porównanie z polską praktyką orzeczniczą, Warszawa 2009, s. 18.

17 Nie chodzi tu w żadnym wypadku tylko o stwierdzenie co do faktu. Por. P. Darbyshire, English Legal System, Sweet \& Maxwell, London 2001, s. 22; J.W. Harris, Precedent in English Law, Clarendon Press, Oxford 1999, s. 40.

18 Definicja za R. Crossem, por. P. Darbyshire, Enlglish Legal System..., op. cit., s. 22; K. Bagan-Kurluta, Sprawy rodzinne.., op. cit., s. 22.

19 https://e-justice.europa.eu/content_member_state_law-6-ie-pl.do?member=1 (8.07.2014). 
zgodny z konstytucją, to powinien odczytać go tylko w taki sposób, w jaki postrzegany jest jako konstytucyjny. ${ }^{20}$

Przedmiotem postępowania toczącego się przed High Court było szereg kwestii, począwszy od samej dopuszczalności i legalności podejmowania czynności poprzedzających wszczęcie sprawy przed sądem.

1. Możliwość dokonania korekty błędu w aktach stanu cywilnego

W świetle Status of Children Act z 1987 r., gdy rodzice dziecka są małżeństwem stosowane jest domniemanie ojcostwa męża matki. Natomiast gdy mężczyzna nie jest mężem matki, na podstawie art. 22 (1) Civil Registration Act z 2004 r., nie ciąży na nim obowiązek podania informacji odnośnie swego ojcostwa do rejestru stanu cywilnego. W takim przypadku oboje - kobieta (matka) i mężczyzna (nie będący mężem matki) mogą razem przybyć do urzędu stanu cywilnego i oświadczyć, że mężczyzna jest ojcem dziecka. Natomiast art. 30 wspomnianego Civil Registration Act nakłada na szpital obowiązek przekazania do rejestru informacji dotyczących szczegółów narodzin dziecka.

Korekta błędu w sprawie odbyć się miała na podstawie listu wysłanego już po rejestracji, dowodu z analizy DNA potwierdzającego, że CR była genetyczną matką bliźniąt i listu z kliniki IVF opisującego przebieg zdarzeń. Superintendent Registar postanowił przeprowadzić w tej sprawie dochodzenie, wynikające z art. 65 Civil Registration Act, aby finalnie uznać, że nie miał uprawnienia do wprowadzenia korekty - ponieważ z otrzymanej przez niego opinii prawnej wynikało, że właściwą do stosowania w przypadkach dochodzenia macierzyństwa jest zasada mater semper certa est. W opinii urzędnika, nie można mówić o czyjejkolwiek prywatnej zdolności do nadania statusu rodzica opartego wyłącznie na zamiarze. Konstytucja określa jako matkę kobietę, która urodziła dziecko, a to nie może być zmienione przez czyjąś intencję. Co za tym idzie, tylko za pośrednictwem mechanizmu przewidzianego w przepisach prawa adopcyjnego jest możliwe pozbawienie siebie statusu rodzica. Ponadto nie jest możliwe, aby tylko ze względu na bycie tzw. rodzicem genetycznym faktycznie mieć dziecko: genetyczni rodzice są w stanie wyprodukować blastocysty, a matka genetyczna może produkować komórki jajowe, ale to nie jest życie.

Rejestr stanu cywilnego jest dokumentem historycznym, w którym zapisywane są fakty i wydarzenia z daty urodzenia. Ma odzwierciedlać zdarzenie urodzenia, a nie jest dokumentem służącym do rejestracji późniejszych wydarzeń w istnieniu danej osoby, lub jakiegokolwiek innego zdarzenia, bez względu na jego znaczenie. Cel rejestru został przedstawiony w orzeczeniu w sprawie Foy v. An tArd Chlára- 
Korekcyjna funkcja słuszności w prawie rodzinnym - kilka refleksji na marginesie wyroku...

itheoir ${ }^{21}$ : „Powstały rejestr jest dokumentem o wartości historycznej, jest aktualny tylko w chwili urodzenia, a nie poza nią. Jest to nie więcej niż to".

2. Możliwość zastosowania konstrukcji wzruszalnego domniemania w odniesieniu do macierzyństwa

Superintendent Registar zapytany o dające się obalić domniemanie ojcostwa i możliwość jego transponowania do macierzyństwa, stwierdził, że „fakt, macierzyństwa to jest fakt prawny”, a „ojcostwo jest wzruszalnym domniemaniem”, są one „koncepcyjnie różne.” Skarżący wnoszą o stwierdzenie, że CR jest matką MR i DR na podstawie art. 35 Status of Children Act z 1987 r. Byłoby to możliwe w przypadku, gdyby istniało wzruszalne domniemanie, że kobieta, która rodzi dziecko, jest jego matką. Takie wzruszalne domniemanie w odniesieniu do ojcostwa nie powoduje żadnych problemów natury administracyjnej. Rozwiązanie zaproponowane przez skarżących odpowiednio chroni interesy państwa i w tym samym czasie umożliwia realizację praw konstytucyjnych wszystkich wnioskodawców. Zgodnie z art. 35 (1) Status of Children Act dziecko może uzyskać wydaną przez sąd deklarację, że osoba jest jego ojcem lub matką. Na podstawie ust. 4, w przypadku niepełnoletniego sąd może odmówić rozpoznania sprawy, jeśli dalsze procedowanie byłoby sprzeczne z dobrem dziecka. Część VII ustawy dotyczy wykorzystania badań krwi w ustalaniu pochodzenia dziecka w postępowaniu cywilnym. W zawartym tam art. 38 (1) przyjęto, że sąd może nakazać wykorzystanie badań krwi w celu ustalenia pochodzenia dziecka. Artykuł ten ma zastosowanie tak w przypadku matek, jak i ojców. Wynika $\mathrm{z}$ tego, że badania krwi mogą być stosowane w celu ustalenia, czy dana osoba jest czy nie jest ojcem lub matką innej osoby. Testy służą ustaleniu obecności dziedzicznych cech wspólnych między dwojgiem ludzi. W art. 37 zdefiniowano badanie krwi jako ,jakikolwiek test przeprowadzony na mocy niniejszej części, a wykonany w celu ustalenia cech dziedzicznych". Z drugiej jednak strony celem regulacji ustawowej jest stwierdzenie pochodzenia dziecka, gdy istnieje nieporozumienie co do tożsamości jego matki, a więc kobiety, która je urodziła. Przepisy nie mogą mieć zastosowania do matki genetycznej - w celu dochodzenia stwierdzenia pochodzenia od niej dziecka, ponieważ takie pojmowanie matki nie mieści się w definicji konstytucyjnej pojęcia „matka”. Takie nieporozumienie może mieć miejsce w przypadku zamiany dzieci w szpitalu i wówczas badanie krwi, które określi cechy genetyczne może być pomocne sądowi w stwierdzeniu pochodzenia dziecka i wydaniu w tej kwestii deklaracji. ${ }^{22}$ Jednak przepisy te nie mają zastosowania do osób w sytuacji wnioskodawcy, który domaga się stwierdzenia macierzyństwa wyłącznie na podstawie genetyki. Ponadto nie jest możliwe, aby wprowadzić wzruszalne domniemanie macierzyństwa, z racji na wartości konstytucyjne - w końcu to Konstytucja definiuje matkę. Jednak 
można także przyjąć, że prawo wymaga elastyczności przy użyciu konstrukcji domniemania, gdy mamy do czynienia z postępami medycyny - a takie domniemanie powinno działać na korzyść rodziców socjologicznych. Aby macierzyństwo kobiety, która urodziła dziecko pozostawić w sferze domniemania, zaistnieć powinny określone okoliczności: 1) osoba inna niż kobieta, która urodziła dziecko dostarczyła komórkę jajową, z której poczęte zostało dziecko, 2) istnieje porozumienie między matką gestacyjną (jeśli jest zamężna i mieszka z mężem - także między nim), matką genetyczną i ojcem, że dziecko będzie traktowane i wychowywane jako dziecko ojca i matki genetycznej, 3) obalenie domniemania jest w najlepszym interesie dziecka, 4) obalenie domniemania nie jest sprzeczne z porządkiem publicznym.

\section{Implikacje noszenia ciąży przez obcą dziecku genetycznie kobietę}

Pierwszoplanowe znaczenie dla przyjęcia koncepcji macierzyństwa genetycznego w oderwaniu od tzw. biologicznego było określenie wpływu, jaki może na dziecko mieć osoba, która nosi ciążę. Stwierdzono, że mimo różnych czynników, które za przyczyną matki gestacyjnej mogą mieć wpływ na dziecko w okresie płodowym, to w żaden sposób nie ma ona wpływu na DNA dziecka - a więc jego genetyczne pochodzenie.

\section{Dopuszczalności surogacji}

Przed 2008 r., irlandzkie pary miały łatwy dostęp do brytyjskich instytucji świadczących usługi w zakresie macierzyństwa zastępczego w Wielkiej Brytanii. Po zmianie prawa, trzeba być rezydentem w Wielkiej Brytanii, aby uzyskać dostęp do takich usług. W Irlandii natomiast nie ma przepisów dotyczących surogacji i ze względu na brak pewności prawnej dyrektorzy klinik położniczych starają się nie angażować w działania prowadzące do surogacji. Żaden przepis prawa irlandzkiego nie zakazuje jednak zawierania takich umów.

W opinii strony powodowej umowa zawarta w tym konkretnym przypadku nie była bezprawnym porozumieniem - co więcej, był to całkowicie altruistyczny akt. Ani Konstytucja, ani Guardianship of Infants Act z 1964 r. wyraźnie nie określa i nie definiuje, kto ma być traktowany jak matka dziecka, z zastrzeżeniem, że art. 2 ustawy z 1964 r. stanowi, że określenie matka obejmuje kobietę adoptującą dziecko. Co więcej, rozwój naukowy w dziedzinie wspomaganego rozrodu człowieka doprowadził do powstawania sytuacji, w których zaistnieć może rozbieżność pomiędzy tożsamością matki genetycznej i gestacyjnej. W takich okolicznościach rolą sądu jest określenie, komu przysługuje status matki. Z drugiej jednak strony w irlandzkim prawie traktowanie kobiety, która urodziła dziecko jako jego matkę jest fundamentalną zasadą, wywodzoną tak z common law, jak i z Konstytucji. W common law znalazła się na mocy rzymskiej zasady mater semper certa est, w Konstytucji, w art. 40.3.3 pod formułą: „Państwo uznaje prawo do życia dziecka nienarodzonego i, $\mathrm{z}$ uwzględnieniem równego prawa do życia jego matki, gwarantuje swoimi prawami 
jego poszanowanie, i, o ile to możliwe, ochronę i realizację tego prawa." Pewność tego stanowiska została potwierdzona w orzeczeniu w sprawie Roche v. Roche ${ }^{23}$, w którym Sąd Najwyższy analizował pojęcie nienarodzonego dziecka, aby przejść do pojęcia matki.

\section{Znaczenie więzów krwi między dziećmi a rodzicami}

Matka gestacyjna będzie do pewnego stopnia chronić dziecko, ale naturalny związek, który istnieje między matką a dzieckiem jest to związek krwi. Pochodzi od tego, co jest opisane jako czysta genetyka i nie może być w nim elementu gestacyjnego (ciążowego). Supreme Court przyjął, przy różnych okazjach w odniesieniu tak do matki, jak i ojca, o istnieniu związku krwi lub więzi krwi. Logicznie, że w odniesieniu do ojców może oznaczać to tylko pochodzenie genetyczne, ponieważ w niektórych przypadkach ojcowie w ogóle nie mieli kontaktu ze swoimi dziećmi. Emocjonalne i fizyczne więzi między kobietą i dzieckiem, które urodziła dają jej prawa, które wypływają z prawa natury, a które zostały uznane w common law na długo przed przyjęciem Konstytucji (G v. An Bord Uchtála ${ }^{24}$ ), a prawa ojca, jeśli istnieją, a wynikają wyłącznie z relacji biologicznej pomiędzy ojcem i synem są mało istotnym czynnikiem przy ustalaniu przez sąd, czy wydać rozporządzenie w kwestii opieki nad dzieckiem (WOR v. $\mathrm{EH}^{25}$ ).

Irlandzkie orzecznictwo jest pełne odniesień do związku krwi pomiędzy matkami, ojcami i ich dziećmi. Przez ponad 100 lat sądy uznawały znaczenie i istnienie tego, co zostało określone jako „związek krwi” czy „więzi krwi” między dziećmi i rodzicami.

N v. Health Service Executive ${ }^{26}$ : jest pierwotną zasadą konstytucyjną, że dobro dziecka jest najlepiej realizowane w sercu jego naturalnej rodziny. Jest zasadą konstytucyjną, która odzwierciedla podstawowe, pierwotne prawo natury (sprawa dotyczyła akceptacji znaczenia związku krwi lub naturalnego związku, który istnieje między dzieckiem a jego rodzicami).

G v. An Bord Uchtála: matka ma na mocy artykułu 40.3.1 Konstytucji osobiste prawo do ochrony, opieki i pieczy nad swoim dzieckiem będącym w wieku niemowlęcym; jako matka ma prawa, które wynikają z faktu macierzyństwa i z samej natury; jej prawa wyraźnie opierają się na naturalnym związku, który istnieje między matką a dzieckiem.

I.O'T v. B and Others ${ }^{27}$ : istnieje konstytucyjne prawo do poznania tożsamości własnej matki, które równoważy prawo do prywatności matki dziecka, które zostało 
oddane do adopcji. Potrzeba trzymania otwartych drzwi jest oparta na genetyce: pomoc od członka rodziny może być istotna w niektórych chorobach.

J.K v. V.W. and Others ${ }^{28}$ : związek krwi między niemowlęciem a ojcem i dana dziecku możliwość korzystania z opieki i towarzystwa jego ojca jest jednym z wielu czynników, które mogą być oceniane przez sąd jako istotne dla jego dobra.

J.McD v. $\mathrm{PL}^{29}$ : postęp naukowy uczynił nas świadomymi, że nasz unikalny genetyczny makijaż wynika z dwóch niezależnych, ale równie unikalnych źródeł materiału genetycznego. To jest aspekt dobra dziecka.

\section{Konstytucyjna i ustawowa ochrona więzi rodzinnych}

W kontekście rodziców będących małżonkami o ochronie więzi lub związku krwi można mówić na podstawie art. 41 i 42 Konstytucji: domniemywa się, że dzieci powinny być wychowywane przez rodziców i mogą być odebrane im bądź przez nich niewychowywane tylko $\mathrm{w}$ sytuacji naruszenia obowiązku zgodnie z art. $42.5^{30}$ lub jeżeli istnieją ważne powody.

Jeśli CR nie jest rozpoznawana jako matka dzieci, to one, żyjąc z nią i jej mężem i pod każdym względem praktycznym wykazując zewnętrzne oznaki rodziny, są pozbawione rzeczywistego uznania i bezpieczeństwa, które wynika $\mathrm{z}$ faktu bycia prawnie uznaną rodziną, a to godzi w ich prawa wynikające z art. 41 i 42.

Prawa małżonków CR i OR, zgodnie z art. 41, 42 i 40.3 do kształcenia, ochrony i opieki nad bliźniętami i współzależne $\mathrm{z}$ nimi prawa bliźniąt do wykształcenia i opieki są również zagrożone. Bliźniacy mają prawo do takiej samej ochrony, jak inne dzieci w tym zakresie, a okoliczności ich poczęcia nie powinny ich jej pozbawić.

Dziecko ma osobiste prawo, zgodnie z art 40.3 Konstytucji do tego, aby decyzje w odniesieniu do opieki nad nim, pieczy lub wychowania podejmowane były w jego najlepszym interesie. ${ }^{31}$ Nie byłoby w najlepszym interesie bliźniąt, gdyby w świetle prawa nie miały związku prawnego lub praw w odniesieniu do CR i OR.

Istnieje obowiązek państwa chronić i bronić praw własności stron, wynikający z art 40.3. Brak uznania CR za matkę bliźniąt będzie miał znaczący wpływ na prawa własności jej samej, dzieci oraz jej siostry. Jeżeli w świetle prawa bliźnięta są dziećmi matki zastępczej, w przypadku dziedziczenia ustawowego ${ }^{32}$ nieruchomości będą podzielone między jej wszystkie dzieci (oprócz bliźniąt urodziła jeszcze dwójkę dzieci) - na cztery części, w przeciwieństwie do dwóch, gdyby uznać

[1992] 2 IR 437.

[2010] 2 IR 199.

W wyjątkowych przypadkach, gdy rodzice z fizycznych albo moralnych przyczyn nie wypełniają swych obowiązków względem dzieci, państwo jako strażnik dobra wspólnego, poprzez odpowiednie działania, próbuje wypełniać zadania w miejsce rodziców, ale zawsze z należytym szacunkiem dla naturalnych i nienaruszalnych praw dziecka.

In FN \& Anor v. CO \& Anor [2004] IEHC 60 (unreported 23rd March, 2004), DG v. The Eastern Health Board [1997] 3 IR 511.

Tzw. intestacy, czyli dziedziczenie w sytuacji, gdy spadkodawca nie zostawił rozporządzenia na wypadek śmierci. 
odmiennie. Natomiast bliźniacy nie będą uprawnieni do automatycznego udziału w majątku matki genetycznej przy dziedziczeniu ustawowym.

Brak uznania CR za matkę ma wpływ na prawo do zawarcia małżeństwa. Jeżeli w świetle prawa bliźnięta są dziećmi matki genetycznej, są tym samym kuzynami3 ${ }^{33}$ synów jej siostry. W irlandzkim prawie istnieje możliwość poślubienia swojego kuzyna. Jeśli są one zaś dziećmi siostry swojej matki genetycznej, nie mogą wstąpić w związek małżeński ze swoim rodzeństwem.

W związku z art 40.1 Konstytucji naruszone zostało prawo do równego traktowania. Brak uznania CR za matkę jest przejawem jej dyskryminacji z powodu niezdolności do poczęcia i urodzenia w normalny sposób (może być traktowana jako niepełnosprawność). O bezprawnej dyskryminacji można także mówić w kwestii oceny pochodzenia - w przypadku mężczyzn uzależniona jest ona wyłącznie od czynników genetycznych, w odróżnieniu od kobiet.

Finalnie sąd uznał za zasadne żądania powodów, powodując się następującymi względami.

Maksyma mater semper certa est jest częścią serii maksym odnoszących się do macierzyństwa i ojcostwa, a wywodzących się z prawa rzymskiego. Maksyma uzyskała takie znaczenie, akceptację i stałość w stosowaniu w związku z faktem, że przed IVF matka dziecka była ustalona w przebiegu porodu, a maksyma (będąca niepodważalną prawdą) odzwierciedlała fakty. W common law maksyma stała się domniemaniem prawnym i faktycznym. Ponieważ opierała się na niepodważalnych faktach, stała się tzw. niewzruszalnym domniemaniem w postępowaniach sądowych. Oznaczało to uznawanie macierzyństwa kobiety w odniesieniu do dziecka, gdy urodzenie go przez nią zostało udowodnione. Nie wymagano żadnych innych dowodów lub argumentów, a sprawa była oczywista. Żadne dowody dla zakwestionowania domniemania nie mogły być przedstawiane. Jeśli jakikolwiek byłby dopuszczony przez prawo, to domniemanie zmieniłoby się z niewzruszalnego we wzruszalne. Mogłoby być obalone każdym właściwym dowodem. Przed umowami macierzyństwa zastępczego możliwość obalenia mater semper certa est nie powstała. Podstawową kwestią w sprawie jest to, czy możliwość taka powstaje w ramach istniejących w Irlandii ram prawnych i konstytucyjnych.

Harmonijna wykładnia przepisów Konstytucji wymaga, aby słowo „matka” miało takie samo znaczenie w całej konstytucji, w przepisach Status of Children Act i wszystkich innych właściwych przepisach prawnych. Słowo „matka” w tym artykule Konstytucji (zdaniem sądu) ma znaczenie specyficzne dla samego artykułu, wiążące go z istnieniem nienarodzonych dzieci, co zostało już podniesione przez $\mathrm{Su}$ - 
preme Court w sprawie dotyczącej zamrożonych zarodków (Roche v. Roche) i powinno się odnosić tylko do sytuacji, gdy płód był w łonie matki.

Jak wynika z orzeczeń w sprawach N v. Health Service Executive i J.McD v. PL, pojęcie więzi lub związków krwi jest najważniejsze przy podejmowaniu decyzji dotyczących rodzicielstwa. Należy określić, co sądy rozumiały przez określenie związków „krwi”. W przypadku ojcostwa było to dość łatwe do ustalenia. Sąd doszedł do przekonania o rozstrzygającym charakterem chromosomalnego DNA oraz o konieczności uszanowania i traktowania z troską i rozwagą, które nakazuje najlepsza praktyka lekarska wkładu matki gestacyjnej w zarodek oraz płód nie zawierający jej materiału genetycznego. Dominujący determinizm materiału genetycznego w komórkach płodu pozwala na rzetelne zastosowanie do niego obowiązujących przepisów dla ustalania ojcostwa. Byłoby krzywdzące, nieracjonalne i niesprawiedliwe zrobić to w inny sposób. Ta konkluzja znajduje wsparcie w obecnej praktyce prawodawczej w postaci Adoption Act z 2010 r., w której ustawodawca uznał znaczenie relacji krwi.

Ostatnim istotnym problemem, z którym zmierzył się sąd była odpowiedź na pytanie, czy w świetle powyższych wniosków z orzeczenia w odniesieniu do rzetelnego porównania sytuacji ojców i matek, w celu ustanowienia relacji z krwi i wykonalności testów DNA matek dla ułatwienia rejestracji, stosowania maksymy mater maxim semper certa est jako niewzruszalnego domniemania jest zgodne $\mathrm{z}$ uczciwymi procedurami określonymi w Konstytucji. Wyrok w sprawie S v. S dotyczący niewzruszalnego domniemania, w niektórych przypadkach odnoszących się do ojcostwa w małżeństwie, jest wystarczającą podstawą, aby umożliwić sądowi stwierdzenie, że domniemanie mater semper certa est nie przeżyło uchwalenia Konstytucji w zakresie, w jakim odnosi się do sytuacji po IVF. Dla osiągnięcia uczciwego i sprawiedliwego rozwiązania, zarówno dla genetycznych ojców jak i matek, dochodzenie macierzyństwa powinno być dokonane w oparciu o materiał genetyczny - a po udowodnieniu pochodzenia matka genetyczna powinna być zarejestrowana jako matka dziecka na podstawie przepisów Civil Registration Act z 2004 r. Taki wniosek nie wymaga nawet podnoszenia kwestii dobra dziecka, któremu w większości przypadków, jeśli nie we wszystkich, najlepiej służyłoby dochodzenie pochodzenia genetycznego.

W świetle powyższych uwag nasuwa się pytanie, czy analogiczne rozwiązanie mogłoby zaistnieć na gruncie polskim? Na pierwszy rzut oka, wydawać się może, że nie. $\mathrm{W}$ przeciwieństwie do irlandzkiego w polskim systemie prawnym znajduje się wyraźna regulacja ustawowa jasno wskazująca jako matkę dziecka kobietę, która 
je urodziła (art. $61^{9}$ k.r.o. ${ }^{34}$ ). Poza tym art. 87 Konstytucji RP ${ }^{35}$ jednoznacznie wskazuje, iż źródłami prawa powszechnie obowiązującego na terenie Rzeczypospolitej Polskiej są: Konstytucja, ustawy, ratyfikowane umowy międzynarodowe oraz rozporządzenia, a także akty prawa miejscowego, na obszarze działania organów, które je ustanowiły. Przy czym system aktów prawa powszechnie obowiązującego ma charakter zamknięty. W aspekcie przedmiotowym oznacza to wyczerpujące określenie aktów prawnych posiadających tenże charakter, w aspekcie podmiotowym zaś wyczerpujące określenie organów władzy publicznej wyposażonych w kompetencje prawotwórcze, którymi są: Sejm, Senat, Prezydent RP, Rada Ministrów, Prezes RM, ministrowie kierujący określonymi działami administracji rządowej, przewodniczący komitetów powoływanych w skład RM, Krajowa Rada Radiofonii i Telewizji. ${ }^{36}$ Brak jak widać w owych katalogach orzeczenia sądowego (precedensu), jako źródła prawa powszechnie obowiązującego, jak i sądu jako podmiotu posiadającego kompetencje prawotwórcze. W związku z tym, aby odpowiedzieć na zaprezentowane powyżej pytanie, należy uprzednio rozstrzygnąć dwie kwestie: 1) czy na gruncie polskiego systemu prawnego precedens stanowi (czy też stanowić może) źródło prawa powszechnie obowiązującego?; 2) w razie pozytywnej odpowiedzi na owo pytanie, czy takowe orzeczenie ,przełamuje” (może ,przełamać”) jednoznaczną normę wynikającą z wyraźnego przepisu ustawy?

Odnosząc się do pierwszego z zagadnień zauważyć należy, że jakkolwiek system źródeł prawa ma na gruncie prawa polskiego charakter zamknięty, to jednak owo ,zamknięcie” dotyczy, jak podkreśla się w piśmiennictwie, tzw. prawa stanowionego (pisanego) przybierającego postać aktów normatywnych. Nie wyklucza ono natomiast istnienia prawa niepisanego, przez które rozumie się normy o charakterze ogólnym nie wypływające bezpośrednio ze źródeł prawa ujętych w rozdziale trzecim Konstytucji RP (tudzież z art. 234 ustawy zasadniczej), lecz z innych faktów prawotwórczych, ${ }^{37}$ funkcjonujących w rzeczywistości jako normy mające za sobą autorytet Konstytucji. ${ }^{38}$ Tak więc przyjęta regulacja konstytucyjna nie wyklucza istnienia precedensu jako źródła prawa, ${ }^{39}$ a tym samym nie wyklucza istnienia innych niż wskazane powyżej podmiotów wyposażonych w kompetencje prawotwórcze. Podmiotem takim w interesującym nas kontekście będzie sąd, jako że w prawie zasadnicze znaczenie odgrywają precedensy sądowe. ${ }^{40}$ Tak więc tego typu decyzja

\footnotetext{
34 Ustawa z dnia 25 lutego 1964 r. - Kodeks rodzinny i opiekuńczy (t. jedn. Dz.U. z 2012 r. poz. 788 z późn. zm.).

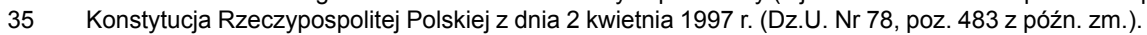

36 K. Działocha, uwagi 3 i 6 do art. 87 Konstytucji w: Konstytucja Rzeczypospolitej Polskiej. Komentarz, t. 1, L. Garlicki (red.), Warszawa 1999, s. 2, 6.

37 Termin „źródła prawa” w swym podstawowym znaczeniu odnosi się do faktów tworzących prawo (faktów prawotwórczych) - S. Wronkowska, (w:) S. Wronkowska, Z. Ziembiński, Zarys teorii prawa, Poznań 2001, s. 141.

38 Por. A. Gomułowicz, Sędzia sądu administracyjnego a prawotwórstwo sądowe - zasadnicze dylematy, „Zeszyty Naukowe Sądownictwa Administracyjnego" 2007, nr 4, s. 16.

39 Por. np. B. Banaszak, Konstytucja Rzeczypospolitej Polskiej. Komentarz, Warszawa 2009, s. 428.

40 Por. N. Duxbury, The Nature and Authority of Precedent, New York 2008, s. 1. Na marginesie zauważyć także należy, iż na gruncie polskiej teorii prawa termin precedens rozumiany jest z reguły właśnie jako orzeczenie sądowe (a właściwie zawarta w nim norma ogólna - o czym była już mowa) - zob. A. Orłowska, Stosowanie a tworzenie
} 
może stanowić źródło prawa w naszych realiach, ba, stanowi je (zob. niżej). Konstatacja ta pociąga jednakże za sobą kolejne pytanie, tym razem o charakter tego faktu prawotwórczego. W piśmiennictwie wskazuje się, że źródła prawa podzielić można na pierwotne (samoistne) oraz wtórne (niesamoistne). O źródłach pierwszego typu mówi się, gdy reguła lub zasada z nich wypływająca stanowić może samodzielną podstawę decyzji sędziowskiej lub innego aktu stosowania prawa, a zatem może być samodzielnym źródłem uprawnień lub obowiązków podmiotów prawa. O źródle niesamoistnym mówi się z kolei, gdy reguła lub zasada zeń wypływająca nie będzie mogła stanowić samodzielnej podstawy aktu stosowania prawa, a zatem również samodzielnego źródła uprawnień i obowiązków podmiotów prawa. ${ }^{41}$ Zgodnie z jednym z klasycznych założeń doktryny w krajach prawa stanowionego precedens stanowić może jedynie niesamoistne źródło prawa. ${ }^{42}$ Niemniej jednak wyrażony został również pogląd, zgodnie z którym precedens może być nie tylko niesamoistnym, ale także samoistnym źródłem prawa. ${ }^{43}$ Ze stanowiskiem tym należy się zgodzić. O jego trafności świadczy m.in. historia instytucji jurysdykcji krajowej koniecznej. Obecnie materia ta uregulowana jest w art. $1099^{1}$ k.p.c. ${ }^{44}$ Zanim jednak wprowadzono ten przepis ustawą z dnia 5 grudnia 2008 r. o zmianie ustawy - Kodeks postępowania cywilnego oraz niektórych innych ustaw, ${ }^{45}$ jurysdykcja krajowa konieczna funkcjonowała jako instytucja wprowadzona do polskiego sytemu prawnego precedensową uchwałą SN z dnia 31 maja 1975 r. $^{46}$ - wytwór orzecznictwa ${ }^{47}$ - która to uchwała stanowiła samoistne źródło rekonstrukcji normy prawnej ${ }^{48}$ (źródło prawa), do którego odwoływały się sądy rozpatrujące analogiczne przypadki. ${ }^{49}$ Należy także zauważyć, iż owa uchwała (reguła ogólna w niej zawarta) stanowi przykład precedensu prawotwórczego, tj. zawierającego element nowości normatywnej (zmiana zakresu czynów nakazanych, zakazanych lub dozwolonych) w stosunku do stanu poprzednio uregulowanego, czy też w nieco innej konwencji, przykład precedensu rozstrzygnię-

prawa w Polsce (uwagi o roli orzecznictwa sądowego w systemie źródeł prawa), „Przegląd Sądowy” 1999, nr 10, s. 90.

41 Por. L. Morawski, Czy precedens powinien być źródłem prawa?, (w:) J. Malarczyk (przewodniczący kom. red.), W kręgu problematyki władzy, państwa i prawa. Księga jubileuszowa w 70-lecie urodzin Profesora Henryka Groszyka, Lublin 1996, s. 189-190.

42 Zob. Ibidem, s. 192.

43 Por. L. Leszczyński, Precedens jako źródło rekonstrukcji normatywnej podstawy decyzji stosowania prawa, (w:) I. Bogucka, Z. Tobor (red.), Prawo a wartości. Księga jubileuszowa Profesora Józefa Nowackiego, Kraków 2003, s. $151,154$. Ustawa z dnia 17 listopada 1964 r. - Kodeks postępowania cywilnego (t.jedn. Dz.U. z 2014 r. poz. 101 z późn. $\mathrm{zm}$.).

45 Dz.U. Nr 234, poz. 1571.

$46 \quad$ III CZP 78/75, LEX nr 1880. 47 Por. np. H. Duszka-Jakimko, Bezpieczeństwo prawne w międzynarodowym postępowaniu cywilnym, (w:) Pro"Gdańskie Studia Prawnicze" 2002, t. 9, s. 67; J. Jodłowski, Jurysdykcja sądów polskich w sprawach spadkowych po cudzoziemcach zamieszkałych w Polsce, „Państwo i Prawo” 1976, z. 6, s. 60-61.

49 Zob. np. uchwała SN z dnia 19 października 1977 r., III CZP 76/77, LEX nr 2211; postanowienie SN z dnia 5 sierpnia 1999 r., II CKN 444/99, LEX nr 38287. 
cia tj. tworzącego nową normę (normy) ${ }^{50}$ Reasumując zatem dotychczasowe rozważania stwierdzić należy, iż precedens w naszym systemie może stanowić i stanowi źródło (także samoistne) prawa powszechnie obowiązującego.

Powyższa konkluzja uprawnia nas do przejścia do drugiej ze wskazanych kwestii, tj. zdolności precedensu do ,przełamania” normy prawnej wynikającej z jednoznacznego przepisu ustawy lub inaczej rzecz ujmując dopuszczalności precedensu contra legem. W piśmiennictwie wskazuje się, iż na gruncie doktryny anglosaskiej wyrażony został pogląd, zgodnie z którym o ile każda ustawa może uchylić precedens, o tyle żaden precedens nie może uchylić ustawy. ${ }^{51}$ Podobne stanowisko zdaje się przeważać w doktrynie polskiej, na gruncie której kwestionuje się dopuszczalność wydawania precedensów (prawotwórstwa) contra legem, ${ }^{52}$ acz nie jest to stanowisko jednomyślne. ${ }^{53}$ Istotnie, wydaje się, że dopuszczalność wydania tego typu precedensu da się uzasadnić na gruncie polskiego systemu prawa kategorią słuszności. Słuszność bowiem stanowi element systemu prawa pozwalający na poszukiwanie podstawy decyzji poza literalnym brzmieniem przepisów. ${ }^{54} \mathrm{~W}$ klasycznym ujęciu pełnić może ona trzy funkcje: dostosowania prawa do indywidualnego przypadku (słuszność infra legem), środka do wypełnienia luk w prawie (słuszność praeter legem) oraz przesłanki uzasadniającej odmowę zastosowania niesprawiedliwego prawa (słuszność contra legem). ${ }^{55}$ Przy czym wydaje się, że przytoczone rozumienie trzeciej z wymienionych funkcji jest zbyt wąskie. W tym kontekście odwołać się należy do kategorii luki contra legem, która oznacza ujemną ocenę obowiązującej regulacji połączoną z postulatem jej uchylenia albo zmiany. ${ }^{56}$ Należy zatem, jak sądzimy, uznać, iż słuszność contra legem stanowi uzasadnienie nie tylko odstąpienia od zastosowania danej normy prawnej, ale co najmniej także jej zmiany (zastąpienia inną normą). Słuszność zatem pozwala nie tylko sprzeciwić się, wyjść poza posłuszeństwo ustawom (odmowa zastosowania normy), ale także naprawiać prawo (modyfikacja; zastąpienie normy), nie dozwalając na wydanie decyzji niesprawiedliwej. ${ }^{57}$ Zgodzić się przy tym należy z tezą, że słuszność sprzeciwia się relatywizmowi, nie może być ona wypełniana dowolną treścią. W związku z tym powstaje pytanie o uzasadnienie dopuszczalności odwołania się do omawianego rodzaju słuszności i posłużenia się prawotwórczym precedensem contra legem. W piśmien-

\footnotetext{
50 Zob. L. Morawski, Główne problemy współczesnej filozofii prawa. Prawo w toku przemian, wyd. 3, Warszawa 2003, s. 255 oraz wskazaną tam literaturę.

51 Ibidem, s. 250

52 Por. np. Z. Kmieciak, Prawotwórstwo sędziowskie w sferze jurysdykcji sądów administracyjnych, „Państwo i Prawo" 2006, z. 12, s. 35 oraz A. Stelmachowski, Zarys teorii prawa cywilnego, Warszawa 1998, s. 308. Por. L. Morawski, Czy precedens..., op. cit., s. 201.

54 Por. W. Dziedziak, Z zagadnień słuszności w prawie, (w:) M. Chrzanowski, J. Kosturbiec, I. Nowikowski (red.), Państwo-prawo-polityka. Księga poświęcona pamięci Profesora Henryka Groszyka, Lublin 2012, s. 100-101.

55 M. Akehurst, Equity and General Principles of Law, „International and Comparative Law Quarterly” 1976, vol. 25, no. 4 , s. 801 .

56 Zob. A. Kozak, Luka aksjologiczna, (w:) A. Bator (red.), Wprowadzenie do nauk prawnych. Leksykon tematyczny, wyd. 4, Warszawa 2012, s. 179.

57 Por. W. Dziedziak, Z zagadnień..., op. cit., s. 99.
} 
nictwie wskazuje się, że stworzenie przez sąd nowej reguły uprawnione będzie, generalnie rzecz biorąc, w przypadku rażącego błędu legislacyjnego, aksjologicznego lub prakseologicznego. Przy czym zgodnie z zasadą subsydiarności działanie takie winno zostać podjęte tylko wtedy, gdy w odpowiednim czasie nie jest tego w stanie uczynić legislator, a zachodzi nagląca potrzeba podjęcia decyzji. ${ }^{58} \mathrm{~W}$ tym kontekście warto także zauważyć, iż w jednym z orzeczeń Trybunał Konstytucyjny odnosząc się do kwestii językowego znaczenia tekstu jako granicy wykładni, zauważył, iż nie jest ona granicą bezwzględną - możliwe jest jej przekroczenie, jednakże muszą za tym przemawiać silne racje aksjologiczne, odwołujące się przede wszystkim do wartości konstytucyjnych. ${ }^{59}$ Wydaje się, że tezę tę odnieść można również do omawianej $\mathrm{w}$ niniejszym artykule problematyki. ${ }^{60}$

Odnosząc się do przedmiotowej kwestii wskazać należy, iż w piśmiennictwie podnosi się, że przyjęte przez polskiego ustawodawcę kryterium macierzyństwa m.in. - „utrudnia wyrokowaniu o macierzyństwie wobec porzuconych noworodków, bo niezgodność cech w parze matka - dziecko może świadczyć o braku pokrewieństwa genetycznego albo o porzuceniu noworodka przez matkę biologiczną, która go urodziła, ale od której on nie pochodzi; ustanawia matką dziecka kobietę, która zgodnie $z$ art. $61^{7}$ [k.r.o. - przyp. aut.] nie jest jego krewną, nawet w linii bocznej; naraża na niemożność ustalenie faktycznych więzów pokrewieństwa relacji matka-dziecko, koniecznych w przypadkach losowych: katastrofy, potrzeba ratowania zdrowia czy życia". ${ }^{61}$ Wskazane konsekwencje trudno uznać za zgodne z zawartą w Konstytucji RP zasadą dobra dziecka, która, jak wskazuje się w doktrynie, stała się „dyrektywą przewodnią uregulowań prawnych". ${ }^{62}$ Ponadto warto zwrócić uwagę na argumentację w omówionym powyżej orzeczeniu M.R\&Anor -v- An tArd Chlaraitheoir \& Ors. Uzasadniając rozstrzygnięcie sędzia Abbott zauważył, iż to geny określają tożsamość oraz determinują rozwój osoby ludzkiej. Dodatkowo pamiętać należy, iż ludzie skłonni są lepiej traktować swych krewnych. ${ }^{63}$ To zaś sprawia, że jeszcze trudniej uznać obowiązującą regulację za zgodną z dobrem dziecka. Ponadto, zauważyć należy, iż w piśmiennictwie wskazuje się, że norma zawarta w art. $61^{9}$ k.r.o. ,naraża na uniemożliwienie ustalenia pochodzenia dziecka od matki, gdyż wszystkie artykuły nowego k.r.o. o ustalenie i zaprzeczenie macierzyństwa zasadzają się na akcie urodzenia dziecka, a nie na jego faktycznym genetycznym przodku (tu: matce) - w konsekwencji naraża godność dziecka, gdyż nie może ono poznać swego od-

58 L. Morawski, Główne problemy..., op. cit., s. 309.

59 Wyrok TK $z$ dnia 28 czerwca 2000 r., K 25/99, LEX nr 41212.

60 Por. L. Morawski, Podstawy filozofii prawa, Toruń 2014, s. 249.

61 E. Raczek, Nowelizacja Kodeksu rodzinnego i opiekuńczego, Rozdziału I Pochodzenie dziecka (Dz.U. 2008, Nr 220, poz. 1431) - uwagi biegłego genetyka sądowego, „Archiwum Medycyny Sądowej i Kryminologii” 2009, t. 59, nr 2, s. $134,135$.

62 Zob. J. Winiarz [w opracowaniu K. Pietrzykowskiego], (w:) K. Pietzykowski (red.), Kodeks rodzinny i opiekuńczy. Komentarz, wyd. 3, Warszawa 2012, s. 23.

63 Zob. np. R. Dunbar, Kinship in Biological Perspective, (w:) N.J. Allen, H. Callan, R. Dunbar, W. James (ed.), Early Human Kinship. From Sex to Social Reproduction, Malden (Massachusetts) 2008, s. 137-139. 
matczynego pochodzenia" - tymczasem Konstytucja RP wyraźnie nakazuje ochronę i poszanowanie godności (art. 30) - a także ,dyskryminuje kobiety w ogóle, gdyż mężczyźni zgodnie ze znowelizowanym k.r.o. dochodzą swego ojcostwa genetycznego, zaś kobiety nie" ${ }^{44}$ - tymczasem zgodnie z art. 33 ust. 1 Konstytucji RP kobiety i mężczyźni mają równe prawa w życiu rodzinnym, politycznym, społecznym i gospodarczym. Na aspekt „,równościowy” zwrócono także uwagę w omówionym orzeczeniu irlandzkim, gdzie zauważono, iż dochodzenie macierzyństwa winno opierać się na kryterium genetycznym, jako że dzięki temu uczyni się zadość słuszności oraz konstytucyjnej i naturalnej sprawiedliwości względem obojga rodziców dziecka. Powyższe rozważania prowadzą do wniosku, że ingerencja sądu w postaci wydania prawotwórczego orzeczenia contra legem da się uzasadnić na gruncie naszego systemu prawa. Podkreślić przy tym należy, iż rozważania te prowadzone były w optyce typowej, jak się wydaje, dla doktryny polskiej, tj. zakładającej, iż materia dotycząca odmacierzyńskiego pochodzenia dziecka regulowana jest wyczerpująco przez art. $61^{9}$ k.r.o. ${ }^{65}$ Ujęcie to jakkolwiek intuicyjnie wydaje się poprawne, obarczone jest błędem jednokanałowości polegającym na przyjęciu założenia, iż komunikacja przez prawo przebiega właśnie jednokanałowo, gdy tymczasem ma ona charakter wielokanałowy, tzn. po stronie nadawców znajduje się co najmniej kilka podmiotów (prawodawców realnych), których komunikaty musi scalić odbiorca. ${ }^{66} \mathrm{~W}$ owym ujęciu izoluje się fragment tekstu (tu art. $61^{9}$ k.r.o.) od innych komunikatów prawnych (przepisów ustawowych, konstytucyjnych itp.) i uznaje komunikat jednego prawodawcy realnego za komunikat prawodawcy idealnego. Tymczasem w typowej sytuacji odbiorca (np. organ stosujący prawo) otrzymuje komunikaty wielokanałowo, co wynika m.in. z często występującego zbiegu przepisów oraz konstytucjonalizacji współczesnych systemów prawnych. ${ }^{67} \mathrm{Z}$ uwagi na ograniczone ramy niniejszego opracowania odniesiemy się jedynie do drugiej z zaprezentowanych sytuacji, co wynika z roli konstytucji jako najwyższego aktu prawego. Po pierwsze przypomnieć należy, że powyższe rozważania doprowadziły do wniosku, iż obowiązująca regulacja jest niezgodna z aksjologią ustawy zasadniczej. Po drugie zauważyć trzeba, że Konstytucja RP odnosi się do kwestii pochodzenia odmacierzyńskiego. W art. 71 ust. 2 stanowi ona, iż matka przed [podkr. aut.], jak i po urodzeniu dziecka ma prawo do szczególnej pomocy władz publicznych, której zakres określa ustawa. Wykładnia tego przepisu prowadzi do wniosku, iż ustawodawca konstytucyjny przyjął, iż stosunek macierzyństwa powstaje zanim dziecko przyjdzie na świat, co zostało pod-

\footnotetext{
64 E. Raczek, Nowelizacja..., op. cit., s. 134.

65 Por. np. G. Jędrejek, Kodeks rodzinny i opiekuńczy. Pokrewieństwo i powinowactwo. Komentarz do art. $61^{7}-144^{1}$, Warszawa 2014, s. 35-36; J. Strzebińczyk, Prawo rodzinne, wyd. 4, Warszawa 2013, s. 204; A. Zieliński, Prawo rodzinne i opiekuńcze w zarysie, wyd. 2 [zaktualizował G. Jędrejek], Warszawa 2011, s. 166.

66 M. Matczak, Summa iniuria. O błędzie formalizmu w stosowaniu prawa, Warszawa 2007, s. 181.

67 Por. Ibidem, s. 183.
} 
niesione także w doktrynie. ${ }^{68} \mathrm{~W}$ tej zaś sytuacji przyjąć należy, iż kryterium ustalenia macierzyństwa stanowić winna relacja genetyczna (wieź krwi) pomiędzy daną kobietą a dzieckiem, na co wskazują m.in. powyższe rozważania odnośnie negatywnych skutków przyjęcia kryterium urodzeniowego. Konstatacja ta wzmacnia tezę o niekonstytucyjności art. $61^{9}$ k.r.o., która wyłoniła się toku powyższych analiz. To zaś prowadzi do wniosku o koniczności zmiany tejże regulacji. Przy czym z uwagi na praktykę legislacyjną zakładać należy, iż zmiana taka mogłaby się dokonać po upływie stosunkowo długiego czasu, tymczasem instytucja pokrewieństwa stanowi jeden z fundamentów systemu prawa, zatem stosowna regulacja winna zostać wprowadzona jak najszybciej. W konsekwencji stwierdzić należy, iż w omawianym przypadku spełnione zostały warunki uzasadniające wydanie precedensu contra legem. ${ }^{69}$

Procesy zachodzące we współczesnym świecie (np. rozwój prokreacji medycznie wspomaganej) stawiają m.in. prawników (zwłaszcza sędziów) przed koniecznością podejmowania decyzji w sytuacji braku wyraźnych regulacji ustawowych tudzież funkcjonowania stosownych przepisów, które są jednak anachroniczne, czy mówiąc szerzej godzą w podstawowe wartości uznane w danym społeczeństwie, choć na pierwszy rzut oka wydawać się może, iż wpisują się one w aksjologię danego systemu. W tym kontekście zauważyć trzeba, co następuje. Współcześnie załamaniu ulega pozytywistyczny dogmat identyfikujący prawo z ogółem aktów normatywnych obowiązujących w danym państwie. W związku z tym odżywa klasyczne rozróżnienie na ius i lex. ${ }^{70}$ Uznanie owego rozróżnienia oraz stopniowa konwergencja tzw. stanowiska pozytywistycznego i niepozytywistycznego wydaje się nieunikniona. Owa częściowa depozytywizacja prawa pozytywnego sprowadza się do uznania oczywistej wydawałoby się tezy, iż prawo nie jest i być nie może systemem zupełnym, samowystarczalnym, zdolnym niezawodnie korygować pojawiające się w nim błędy i że w związku z tym, gdy zawodzą jego własne normy odwoływać się musi do tych funkcjonujących poza nim. ${ }^{71}$ Istotną rolę w tym kontekście odgrywają reguły słuszności pozwalające na korekturę prawa, które w danym przypadku niedomaga. Odwołanie się do nich nie jest z pewnością zadaniem łatwym, zwłaszcza gdy w konsekwencji doszłoby do wydania orzeczenia (przynajmniej prima facie) contra legem, tak jak w omawianym przypadku. Oznacza to bowiem konieczność grun-

Zob. np. T. Smyczyński, Rodzina i prawo rodzinne w świetle nowej Konstytucji, „Państwo i Prawo” 1997, z. 11-12, s. 190 .

69 O ile, rzecz jasna, orzeczenie niezgodne z ustawą, ale zgodne z konstytucją uznać można za decyzję contra legem.

70 Por. L. Morawski, Główne problemy..., op. cit., s. 240.

71 Zob. ibidem, s. 334. 
townego uzasadniania podjętej decyzji, zwłaszcza w oparciu o aksjologię konstytucyjną oraz gotowość obrony zajętego stanowiska, które według wszelkich znamion prawdopodobieństwa stanie się przedmiotem krytyki części wspólnoty argumentacyjnej. Warto jednak, aby sędziowie, zwłaszcza Sądu Najwyższego, którzy z uwagi na swe usytuowanie w systemie nie muszą obawiać się negatywnej reakcji organów wyższej instancji, podjęli ten trud. Dzięki temu zbliżymy się do ideału prawa rozumianego jako ars boni et aequi oddalając jednocześnie od jego wizji, którą opisać można inną znaną paremią summum ius summa iniuria. 


\section{THE CORRECTIVE FUNCTION OF EQUITY IN FAMILY LAW \\ - SOME REFLECTIONS ON THE MR \& ANOR-V-AN TARD CHLARAITHEOIR \& ORS CASE}

Processes occurring in the modern world such as the development of medically assisted procreation force lawyers to make decisions in the absence of explicit statutory regulations, or in the situation when the relevant provisions, however anachronic, operate - or in broader terms, when they threaten the fundamental values recognized by the community, even though at first glance it may appear that they are part of an axiology of the legal system. The equity rules play an important role in this context, allowing to provide the corrections of law. The reference to them is certainly not an easy task, especially when the consequence would be to give a ruling (at least prima facie), contra legem. However, perhaps because of such judgments we will approach the ideal of law understood as ars boni et aequi rejecting at the same time its vision, which can be described by another well-known maxim: summum ius summa iniuria.

In the Irish case MR \& Anor-v-An Tard Chlaraitheoir \& Ors, the court has issued a precedent perhaps in the double sense of the term: thus - an event preceding and justifying other similar events in the future and the decision of the court serving as an example or justification for resolving similar issues or cases. The court assessed a broad context of an altruistic surrogacy agreement and made a decision that reflects the objective truth about the origin of the children. Perhaps we will have to wait a long time for a similar ruling in Poland - perhaps under the current regime, it will never be issued.

Keywords: equity, surrogate motherhood, Family Law, judical lawmaking, precedent, Polish Legal System 